\title{
Grundtvig-Selskabets årsberetning 2002
}

\section{Af Peter Balslev-Clausen}

Grundtvig-Selskabets årsm øde 2001 blev afholdt den 9. november 2001 i Studenternes Hus, Aarhus Universitet. Ved mødet, der blev afviklet med sognepræst Søren Jensen som dirigent, blev Flemming LundgreenNielsen, Kim Arne Pedersen og Christian Thodberg genvalgt til forretningsudvalget og Peter Balslev-Clausen genvalgt og S. A. J. Bradley nyvalgt til styrelsen. Til revisor blev Bjarne Hansen, Gelsted, valgt. Forretningsudvalget har siden konstitueret sig med Peter BalslevClausen som formand, Flemming Lundgreen-Nielsen som næstformand, Erik Jakob Petersen som kasserer, Kim Arne Pedersen som sekretær, Jens Holger Schjørring, Flemming Lundgreen-Nielsen, Kim Arne Pedersen og S. A. J. Bradley i redaktionen af Grundtvig-Studier og Christian Thodberg som menigt medlem.

Årsmødet blev afholdt $\mathrm{i}$ forbindelse med et seminar, arrangeret af Center for Grundtvigstudier ved Aarhus Universitet, 'Grundtvig i dansk og international kontekst'. Ved dette seminar forelæste højskoleforstander Jørgen Carlsen om 'Exporting Grundtvig - made in Denmark', S. A. J. Bradley om 'Exporting the Word: a Market Report' og Jette Holm om 'Sammenhængen mellem Grundtvigs prædikener og salmer i 1840'erne'.

Forretningsudvalget holdt møde den 21 . januar 2001, og redaktionen har holdt et antal møder i årets $l \varnothing b$.

Det er snart halvandet år siden, at Grundtvig-Selskabet sammen med Center for Grundtvigstudier ved Aarhus Universitet fik sin store forskningsbevilling fra Forskningsministeriet og Carlsberg-Fondet. Arbejdet med udgivelsen af Grundtvigs prædikener fra 1840'erne under ledelse af Christian Thodberg og Jette Holm, oversættelsen af udvalgte værker af Grundtvig til engelsk under ledelse af S. A. J. Bradley, og en kommenteret udgave af Grundtvigs politiske skrifter er nu godt i gang, og det kan allerede nu konstateres, at det arbejde, bevillingen har muliggjort, har medvirket til at give Grundtvig-studiet en fornyet fremdrift. Ikke mindst er der grund til at se oversættelsen af centrale Grundtvig-tekster til engelsk i møde med store forventninger set i sammenhæng med den tiltagende internationalisering af Grundtvig-studiet. I denne sammenhæng skal nævnes den oversættelse til tysk af udvalgte Grundtvig-tekster, der nu nærmer sig sin afslutning.

Fra den norske afdeling af Grundtvig-Selskabet skriver den norske formand, Kirsti Aasen: 
Lørdag 21. september ble det avholdt et dagseminar rundt Synnøve Heggems avhandling, Hva er en salme? Om kjorlighetens makt, maskerade og mosaik i Grundtvigs Sangvaerk (1837) - med godt og vel 30 deltagere. Synnøve Heggem har for $\varnothing$ vrig holdt mange foredrag og salmeaftener rundt omkring i landet siste år - med ovennevnte tema. I januar 2003 er undertegnede invitert til nordnorske kirkedager i Bod $\varnothing$ for å tale om Grundtvigsalmer gjennom kirkeårets høytider. I dagene 13.-15. juni 2003 markerer den norske avdelingen sitt 20 -års jubilæum med et seminar om Grundtvigs kristendomssyn. Vi har også planer om å utvide og forbedre vårt medlemsblad med professionell hjelp fra folkehøyskolens informasjonssenter i Oslo.

Grundtvig-Selskabet er i N. F. S. Grundtvigs Fond repræsenteret af Erik Jakob Petersen. Dette fond, der ifølge sine vedtægter skal støtte det folkelige arbejde med baggrund i den inspiration, der udgår fra Grundtvigs liv og forfatterskab, har i løbet af de sidste år ydet grundbevillingen til den Grundtvig-hjemmeside på internettet, der har fået navnet GrundtvigByen. Her findes en lang række del-hjemmesider og links til andre Grundtvig-relaterede hjemmesider, der viser, hvor langt ud Grundtviginspirationen rækker. Af interesse for den, der ønsker at stifte bekendtskab med Grundtvigs forfatterskab, vil være, at et antal Grundtvig-tekster allerede er skannet og lagt ind på Grundtvig-Byens biblioteks hjemmeside.

Grundtvig-Akademiet, der ledes af Henrik Wigh-Poulsen og har hjemme i Vartov i København, har i det forløbne år fortsat sin både akademiske og folkeoplysende virksomhed. Fra akademiets i GrundtvigSelskabets forstand akademiske virksomhed kan nævnes:

Den 2.-3. februar 2002 gennemførte akademiet i samarbejde med Folkehøjskolernes forening et seminar om 'Dannelse og Duelighed'.

Den 6.-12. maj 2002 afvikledes i samarbejde med Søren Kierkegaard Forskningscentret en konference: 'Grundtvig - Kierkegaard Uge'. Forelæsere var Niels Henrik Gregersen ('Når der bliver mere ud af mindre: Grundtvigs menneskesyn'), Ebbe Kløvedal Reich ('Modsigelsen - en grundtvigsk diagnose'), Pia Søltoft ('For Gud er Alt muligt'), Kim Arne Pedersen ('Sjæle og kroppe i tusindtal (...). Om sammenhængen mellem menneskesyn og kirkesyn hos Grundtvig, undersøgt med baggrund i Søren Kierkegaards forfatterskab'), Kresten Drejergaard ('Grundtvigs vej fra studerekammeret til gudstjenesten'), Morten Kvist ('Grundtvigs kirkesyn. Om 'den kirkelige anskuelse' og sakramental kristendom - 
afslutningen på en historie eller begyndelsen på en ny?'), Britta Schall Holberg ('Det forpligtede liv - om at være en del af en historisk tradition'), Peter Trudvad ('Kierkegaard mod konstitutionen-Medicin mod en Frihedsrus'), Svend Auken ('Det politiske hos Kierkegaard og Grundtvig'), Marianne Jelved ('Den enkelte og fællesskabet'), Henrik Wigh-Poulsen ('Melankoli og profeti. Om Grundtvig, Lundbye og guldalderkunsten'), Joakim Garff ('Hvad har dog ikke denne Pen formaaet (...). Om det æstetiske hos Kierkegaard') og Svend Erik Werner ('Tålt ophold - om den autonome musik, Grundtvig og Kierkegaard i et nutidsperspektiv'). Forelæsningerne er siden udkommet som bog på Forlaget Vartov med titlen Grundtvig - Kierkegaard. En samtale på høje tid.

Som de foregående år stod Grundtvig-Akademiet og Kirkeligt Samfund for et både folkeligt og akademisk arrangement på Grundtvigs fødselsdag den 8. september med foredrag af A. M. Allchin (i anledningen af udgivelsen af en dansk oversættelse af hans bog om Grundtvigs teologi), Johs. Nørregaard Frandsen ('Da solen stod med bonden op. Om Grundtvigs betydning for dansk landbrug.'), Poul Balle-Petersen ('Grundtvigianerne og havedyrkningen') og John Wedell Horsner ('Den grundtvigske bevægelse i kirke- og folkesang').

15.-17. november 2001 afholdt Grundtvig-Akademiet i samarbejde med Folkeuniversitetscentret Skærum Mølle en konference på Folkeuniversitetscentret Skærum Mølle ved Vemb om det naturvidenskabelige verdensbillede i litteraturen, kunsten og den grundtvigske dannelsestradition. Forelæsere var Hans Jørgen Lundager Jensen ('Hverdagens velsignelser'), Erik A. Nielsen ('Om Thøger Larsen'), Henrik Wigh-Poulsen ('De magre heste i rejsestalden - Jakob Knudsen og naturens opbyggelige tale'), Lars Handesten ('Frihåndsvidenskab: omkring Johannes V. Jensens Dyrenes Forvandling'), Ove Korsgaard ('Om mangelen på forståelse mellem folkehøjskolen og den akademiske verden') og Ejvind Larsen ('Hvad med til en afveksling at sætte det egentlige fremskridt på dagsordenen?').

Grundtvig-Bibliotektet i Vartov har nu slået sit navn fast som et af Københavns uundværlige forskningsbiblioteker, der under Liselotte Larsens ledelse betjener stadig flere brugere.

Fra august 2002 er Grundtvig-Biblioteket blevet suppleret af det nyoprettede Vartovarkiv, der er en fortsættelse af Nornesalens arkiv for de folkelige bevægelsers historie. Vartovarkivet, der ledes af Morten Mortensen, er stadig under opbygning og vil som sit formål have at dokumentere og belyse (a) de frie skolers, (b) valg- og frimenighedernes 
og (c) de folkelige foreningers, ikke mindst idræts- og gymnastikbevægelsens, historie.

Af litteraturen om Grundtvig og hans betydning skal nævnes Jakob Ballings oversættelse af A. M. Allchin's N. F. S. Grundtvig. An Introduction to his Life and Work (1998) med den danske titel Grundtvigs kristendom. Menneskeliv og gudstjeneste. Dernæst Svend Bjergs Gud forst og sidst. Grundtvigs teologi - en laesning af Den christelige Børnelaerdom og Henrik Wigh-Poulsens Hjemkomsten og det åbne land. Jakob Knudsens forfatterskab og den grundtvigke realisme. Desuden Jindra Kulichs bog om Grundtvig's Educational Ideas in Central and Eastern Europe and the Baltic States og den allerede nævnte konferencerapport Grundtvig - Kierkegaard. En samtale på høje tid. Som tidligere år bringer også Vartovbogen (2002) læseværdige artikler om den grundtvigske virkningshistorie.

Også i 2002 var Grundtvig-Selskabets årbog Grundtvig-Studier centralt placeret i årets Grundtvig-litteratur med afhandlinger af Jette Holm ('Psalme-Blade til Kirke-Bod. En brevveksling mellem Grundtvig og hans præstevenner i foråret 1843'), S. A. J. Bradley ('A letter home: Grundtvig in Cambridge to his wife Lise, June 1831', 'The Land of the Living. An English translation of Grundtvig's De Levendes Land' og 'Grundtvig's Land of the Living and Anglo-Saxon scholarship in the Royal Library of Copenhagen'), Betina Hjorth Præstegaard ('N. F. S. Grundtvigs syn på forholdet mellem skabelse, åbenbaring og nærværelse belyst ved en sammenligning med Jürgen Moltmann'), Mikkel Crone Nielsen (“'At tale med de døde.' Om sækularisering og hermeneutik i Kaj Thanings forfatterskab' og 'Bibliografi over Kaj Thanings forfatterskab'), Kim Arne Pedersen ('Grundtvig på anklagebænken. En redegørelse for hovedlinjer i de sidste ti års danske Grundtvig-reception og deres forhold til centrale motiver i Grundtvigs forfatterskab og dets virkningshistorie') og Lene Frølund Thomsen ('Livsoplysning og livsfilosofiske perspektiver - et uddannelsesmæssigt modsvar til tidens fokus på kompetenceudvikling').

Grundtvig-forskningen står i disse år usvækket stærkt, både i forbindelse med de etablerede forsknings- og uddannelsessteder og $\mathrm{i}$ andre sammenhænge. Interessen blandt de studerende på universiteterne er ligeledes stadig stor. Ikke desto mindre har man talt om en krise for Grundtvig-receptionen. Der er fra flere sider blevet rejst kritik af den Grundtvig, som tidligere i det store og hele uimodsagt har været opfattet som indbegrebet af det genuint danske. Kritikken skyldes ikke mindst Grundtvigs optagethed af det nationalt danske, som i de senere år er 
blevet taget til indtægt af konservative for ikke at sige reaktionære politiske og kulturelle kredse. Disse kredses brug af den grundtvigske tradition har fået andre til at tage afstand fra, hvad de har opfattet som en fortidig, kulturelt og kirkeligt reaktionær nationalromantik. I betragtning af, at det kun er en snes år siden, en Ejvind Larsen kunne skrive en bog, hvor han nærmest satte lighedstegn mellem Grundtvig og Marx, og højskolerne sværmede for Grundtvig som en dansk Mao Tse-Tung, kan man godt undre sig.

En del af Grundtvig-kritikken skyldes direkte ukendskab til, hvad han sagde og gjorde. Her vil Grundtvig-forskningen kunne bidrage til at klare begreberne og forhindre, at det er et forvrænget Grundtvig-billede, der får lov til at præge opfattelsen af ham. Samtidig må vi fastholde, også inden for Grundtvig-forskningen og -formidlingen, at Grundtvig var en kontroversiel skikkelse i sin samtid, og at han vil være det til enhver tid og ethvert sted, hvor man tager ham alvorligt og for alvor beskæftiger sig med ham.

Grundtvig var i sin samtid og er stadig i dag et både konstruktivt og kontroversielt korrektiv. Han var og er foruroligende kreativ og som sådan en stadig anfægtelse, på én gang bekræftende og irriterende for enhver. På én gang inspirerende, og i det øjeblik man lader sig inspirere af ham den første kritiker af den konkretiserede inspiration, den mest indædte modstander af dem, der tager ham til indtægt. Det ene $\varnothing j$ jeblik bygger han hele universet op og levendegør historiens gang for én, det næste $\varnothing$ jeblik ved man, at man ikke kan følge ham. Det er Grundtvigforskningens opgave mere og mere at afdække, hvem Grundtvig var, hvad han tænkte og følte, og hvad han udrettede. Derved gør Grundtvigforskningen det muligt for os at forholde os stadig mere frit til, hvad Grundtvig var og ville. Grundtvig-forskningen vil derved gøre det muligt for os i stadig højere grad at forarges og anfægtes konstruktivt af Grundtvigs forskellighed fra os og ikke misforstå hans lighed med os. Både internationalt fikserede erhvervsfolk og nationalt bornerte politikere, eller kirkelige og kulturelle aktører, har brug for at blive anfægtet og inspireret af Grundtvig. Derfor har Grundtvig-forskningen en vigtig, for ikke at sige afgørende, rolle at spille i såvel politisk (folkelig!), som kirkelig og kulturel sammenhæng, ikke kun i, som man har sagt 'Grundtvigs fædreland', men i hele den internationale sammenhæng, der i disse år åbner sig for Grundtvig-forskning og Grundtvig-reception.

Der skal også på årsmødet i år lyde en tak til alle, der har hjulpet Grundtvig-Selskabet $\varnothing$ konomisk, administrativt og personligt: Ansatte på Center for Grundtvigstudier ved Aarhus Universitet og på Grundtvig- 
Akademiet og Grundtvig-Biblioteket i Vartov i København, Kirkeligt Samfund repræsenteret af formanden Inge Lise Pedersen og bestyrerparret i Vartov, Kirsten og Hans Grishauge, Statens Humanistiske Forskningsråd og N. F. S. Grundtvigs Fond. Først og fremmest dog alle selskabets medlemmer, der, sammen og enkeltvis, både legemligg $ø \mathrm{r}$ og levendegør den Grundtvig-interesse og det Grundtvig-studium, der er Grundtvig-Selskabets stadige inspiration og forpligtelse. 